\title{
The moose throat bot fly Cephenemyia ulrichii larvae (Diptera: Oestridae) found developing in roe deer (Capreolus capreolus) for the first time
}

\author{
Arne C Nilssen ${ }^{1}$, Marja Isomursu ${ }^{2}$ and Antti Oksanen*2
}

\begin{abstract}
Address: ${ }^{1}$ Tromsø University Museum, NO-9037 Tromsø, Norway and ${ }^{2}$ Finnish Food Safety Authority Evira, Fish and Wildlife Health Research Unit (FINPAR), P.O. Box 517, FIN-90101 Oulu, Finland

Email: Arne C Nilssen - ArneC.Nilssen@tmu.uit.no; Marja Isomursu - Marja.Isomursu@evira.fi; Antti Oksanen* - Antti.Oksanen@evira.fi

* Corresponding author
\end{abstract}

Published: 2 June 2008

Acta Veterinaria Scandinavica 2008, 50:14 doi:10.1186/I75I-0147-50-14

Acta Veterinaria Scandinavica $2008,50.14$ doi.10.1186/1751-0147-50-14

(C) 2008 Nilssen et al; licensee BioMed Central Ltd.

This is an Open Access article distributed under the terms of the Creative Commons Attribution License (http://creativecommons.org/licenses/by/2.0), which permits unrestricted use, distribution, and reproduction in any medium, provided the original work is properly cited.
Received: 21 February 2008

Accepted: 2 June 2008

\begin{abstract}
About fifty larvae of Cephenemyia ulrichii Brauer (Diptera: Oestridae), some of them nearly fullgrown third instars, were found in the throat of a roe deer (Capreolus capreolus) in June 2007 near Helsinki in Finland. The parasite is considered to be host specific, occurring only in the moose (Alces alces), and this paper is apparently the first report of a successful infestation in an aberrant host.
\end{abstract}

\section{Background}

Larvae of throat, or nose or pharyngeal, bot flies in the genus Cephenemyia (Diptera: Oestridae) are obligate parasites that inhabit the nasal cavity, pharynx and throat of cervids [1]. In Europe there are four known species: Cephenemyia trompe (Modeer) in reindeer Rangifer tarandus; Cephenemyia stimulator (Clark) in roe deer Capreolus capreolus; Cephenemyia auribarbis (Meigen) in red deer Cervus elaphus; and Cephenemyia ulrichii Brauer in moose or European elk Alces alces [1-4]. In Finland, Sweden and Norway only C. trompe and C. ulrichii have been reported [3], with the result that Cervus elaphus and Capreolus capreolus are generally not infested by throat bot flies in Fennoscandia (see also [5]). Even though the roe deer population has increased in Finland in the recent decades [6], throat bots have never been reported in roe deer in Fennoscandia.

The moose throat bot fly C. ulrichii was first reported in Finland in 1910 and 1913 [7], and has subsequently become increasingly common in southern Finland $[8,9]$. In Sweden, C. ulrichii was first reported in 1988 [10], but has since increased its distribution [11]. In 1987, the species was reported for the first time in Norway (first instars in Pasvik in northeastern Norway) $[3,4]$. We here report a finding of moose throat bot fly larvae in roe deer.

\section{Methods}

About 50 throat bot fly larvae were seen in an adult roe deer buck shot on 4 June 2007, in Kirkkonummi near Helsinki by the southern coast of Finland. The population consisted of different sized larvae, and three of the bigger ones were collected for laboratory examination. The other larvae were not collected.

Before we could do a proper investigation of the larvae, we considered three species possible: 1) C. stimulator (of roe deer), 2) C. trompe (of reindeer), and 3) C. ulrichii (of moose). As mentioned, C. stimulator has never been found in Finland, whereas C. trompe is common in the northern Finland where there are domestic reindeer, and in the east and central Finland where the wild forest reindeer (Rangifer tarandus fennicus) has a restricted distribution. Cephenemyia ulrichii, on the other hand, is seemingly abundant in 
the moose population (at least up to $66^{\circ} \mathrm{N}$ ), including the Helsinki area.

The specimens, preserved in $70 \%$ ethanol, were investigated using existing keys and descriptions $[1,2]$.

\section{Results and discussion}

The three larvae were about $26-27 \mathrm{~mm}$ long and $7 \mathrm{~mm}$ wide, and therefore definitively in their third and last instar. According to descriptions published [1,2], the third instar larvae of C. ulrichii is distinguished from C. stimulator and C. trompe by having spines irregularly placed on the anterior dorsal side. The spines on C. stimulator and $C$. trompe are placed in regular rows similar to those on the ventral surfaces. The posterior peritremes were also distinctive. All the larval characters coincided with the description of C. ulrichii (Figures 1 and 2).

Generally, all Cephenemyia species are very host specific and thereby also well adapted to their hosts. This host specificity is a product of the fine balance between parasite and host, and the adaptations made by the parasite to survive in the host [12]. In most cases, when an unusual host has been successfully attacked by an oestrid, the parasite will normally not develop properly. This, however, depends in part of how closely the aberrant host is related to the usual host. In the present case, roe deer and moose belong to the same family (Cervidae), although they differ considerably in size. Third instars of $C$. ulrichii reach a length of $40 \mathrm{~mm}$, whereas the specific throat bot fly larvae of roe deer, C. stimulator, reaches a length of $30 \mathrm{~mm}[1,2]$, probably reflecting a restriction imposed by the size of their host.

The larvae in the present study seemed to be nearly fully grown and were probably ready to exit the host for pupation in a few weeks. The date of the find, 4 June, is probably in the middle of the exit period of the larvae. We therefore suggest that these larvae would have succeeded

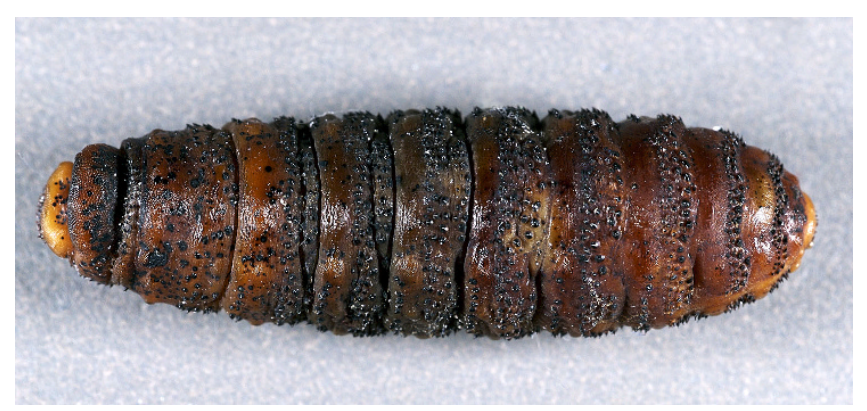

Figure I

Cephenemyia ulrichii third instar larvae from roe deer Capreolus capreolus, dorsal view. Note irregular rows of spines on the anterior dorsal side. Anterior end is the thicker one. in developing in this aberrant host. The smaller size may either be because the larvae were not fully grown, or that the unusual and smaller host prevented the larvae from growing larger. If C. ulrichii larvae in roe deer are not able to reach full size, we could expect failure in pupation process or high mortality/deformation in the adult stage. It has also been observed that if larvae are taken from the host before they are mature, they often fail to pupate [13].

In the Oestridae, some species have only one host species, whereas others parasitize two or more (often closely related) host species [14]. There are several cases reported of other oestrids with seemingly successful development in unusual hosts. The reindeer warble fly, Hypoderma tarandi, has been found to develop into mature larvae in red deer [15], in moose [15,16], and in musk ox (Ovibos moschatus) $[17,18]$. C. ulrichii is regarded as very host specific for the moose [1,2], and development in aberrant hosts has apparently never been reported before. The only published reports we can find where C. ulrichii has attacked other species than moose, are a case in which first instar larvae were found in the conjunctival sac in the eye of a human [19], and another case where 39 young larvae were deposited by a female C. ulrichii on the upper lip of a human [1]. In continental Europe, several large surveys on the throat bot flies on roe deer have been performed (e.g. [20]), but only C. stimulator has been reported. Reindeer throat bot fly larvae have been found in the nasal cavities of dogs in Sweden [21].

Further, a middle-aged woman with ophthalmomyiasis described that while picking forest berries in eastern Finland, she got a big fly in her eye, which was subsequently affected. Following removal, the parasites were morphologically identified as $1^{\text {st }}$ instars of probably C. ulrichii (Sakari Jokiranta and Sauli Laaksonen, unpublished).

\section{Conclusion}

These unusual oestrid - host relationships in Cervidae and other animals, including humans (see review [22]),

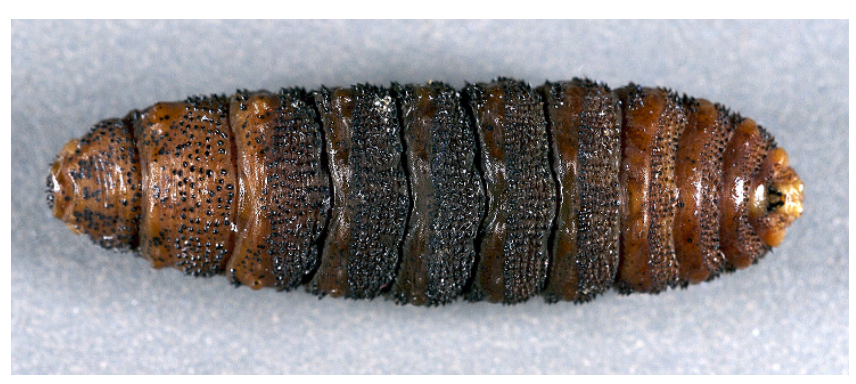

Figure 2

Cephenemyia ulrichii third instar larvae from roe deer Capreolus capreolus, ventral view. Note the more regular rows on the anterior ventral side. 
may be more common than so far considered because, in the normal hunting season in the autumn, the larvae are very small and difficult to detect without specific methods. As a result, even experienced hunters would be unaware of the existence of oestrid fly larvae even in their primary host species. Most reported aberrant host cases, however, only inform that unusual host can be infected, whereas successful development, as the present case, is rarely reported.

\section{Competing interests}

The authors declare that they have no competing interests.

\section{Authors' contributions}

AN was responsible for the parasitological examination and identification of the Oestrid fly larvae, MI handled the hunter-laboratory interface. All authors were involved in drafting the manuscript and gave final approval of the manuscript.

\section{Acknowledgements}

We happily acknowledge Markku Laulumaa, the deer hunter who provided us with the larvae and background information. Rob Barrett is thanked for improving the language.

\section{References}

I. Zumpt F: Myiasis in Man and Animals in the Old World London: Butterworth \& Co;; 1965.

2. Grunin KJ: Oestridae. In Die Fliegen der palaearktischen Region 8 Edited by: Lindner E. Stuttgart: E. Schweizerbart'sche Verlagsbuchhandlung; 1966:1-97. (in German)

3. Nilssen AC, Haugerud RE: Bot flies (Oestridae) parasitizing Scandinavian Cervidae. Trans 19th IUBG Congress: 1989; Trondheim 1990:238-242.

4. Nilssen AC, Haugerud RE: The moose nose bot fly Cephenemyia ulrichii Brauer (Diptera: Oestridae) reported in Norway for the first time. Rangifer 1994, 14:89-92.

5. Andersson H: De svenska styngen. Ent Tidskr 1988, 109:3I-4I. (In Swedish)

6. Pulliainen E: Occurrence and spread of the roe deer (Capreolus capreolus L.) in eastern Fennoscandia since 1970. Memoranda Societatis pro Fauna et Flora Fennica 1980, 56:28-32.

7. Frey R: Cephenomyia ulrichi Brauer, en på älg lefvande, för landet ny oestrid. Medd Soc pro Fauna Flora Fenn 1914, 40:1 I7-II9. (in Swedish)

8. Brander T: Havaintoja hirven nenäsaivartajasta Suomessa [Observations on Cephenomyia ulrichii in moose in Finland]. Suomen Riista 1963, 16:83-91. (In Finnish, with English summary)

9. Valtonen M: [Preliminary study of the prevalence and distribution of nose botfly (Cephenomyia ulrichii Brauer) in the moose in Finland]. Suomen Riista 1972, 24:28-32. (In Finnish, with English summary)

10. Stéen M, Chirico J, Christensson D: Cephenemyia ulrichii Brauer 1862, in Swedish moose. Acta vet scand 1988, 29:265-266.

II. Viklund $B$, Hellqvist $\mathrm{S}$, Bartsch $\mathrm{H}$ : Älgens nässtyng - på spridning i Sverige? Natur i Norr 2003, 22:5I-54. (In Swedish)

12. Colwell DD, Hall MJR, Scholl PJ: Introduction. In The Oestrid Flies: Biology, Host-Parasite Relationships, Impact and Management Edited by: Colwell DD, Hall MJR, Scholl PJ. Wallingford: CAB International; 2006:I-7.

13. Nilssen AC: Pupal biology and Metamorphosis behaviour. In The Oestrid Flies: Biology, Host-Parasite Relationships, Impact and Management Edited by: Colwell DD, Hall MJR, Scholl PJ. Wallingford: CAB International; 2006: 123-138.

14. Colwell DD, Hall MJR, Scholl PJ: A synopsis of the biology, hosts, distribution, disease significance and management of the genera. In The Oestrid Flies: Biology, Host-Parasite Relationships, Impact and Management Edited by: Colwell DD, Hall MJR, Scholl PJ. Wallingford: CAB International; 2006:220-305.

15. Nilssen AC, Gjershaug JO: Reindeer warble fly larvae found in red deer. Rangifer 1988, 8:35-37.

16. Ågren E, Chirico J: Reindeer warble fly larvae (Hypoderma tarandi) in a moose (Alces alces) in Sweden. Acta vet scand 2005, 46: $101-103$

17. Grunin KJ: Hypodermatidae. In Die Fliegen der palaearktischen Region Edited by: Lindner E. Stuttgart: E. Schweizerbart'sche Verlagsbuchhandlung; 1965:I-160. (In German)

18. Jansen J Jr: Hypodermatid larvae (Diptera: Hypodermatidae) from the musk ox, Ovibus moschatus. Ent Ber Amst 1970, 30:222-224.

19. Mikkola K, Silvennoinen J, Hackman W: Hirven nenäsaivartajan aiheuttama ihmisen oftalmomyiaasi. Duodecim 1982, 98: 1022-1025. (In Finnish)

20. Dudzinski W: Studies on Cephenemyia stimulator (Clark) (Diptera, Oestridae), the parasite of the European roe deer, Capreolus capreolus (L.). I. Biology. \& II. Invasiology. Acta parasit pol 1970, 18:555-592.

21. Ström G: Fallbeskrivning. Korm, styngflugelarver, påvisade i hundens näshåla. Svensk Veterinärtidning 1990, 42:571-572.

22. Kearney MS, Nilssen AC, Lyslo A, Syrdalen P, Dannevig L: Ophthalmomyiasis caused by the reindeer warble fly larva. J Clin Pathol |99|, 44:276-284.
Publish with BioMed Central and every scientist can read your work free of charge

"BioMed Central will be the most significant development for disseminating the results of biomedical research in our lifetime. "

Sir Paul Nurse, Cancer Research UK

Your research papers will be:

- available free of charge to the entire biomedical community

- peer reviewed and published immediately upon acceptance

- cited in PubMed and archived on PubMed Central

- yours - you keep the copyright

Submit your manuscript here:

http://www.biomedcentral.com/info/publishing_adv.asp
BioMedcentral 